\title{
POTENSI SERANGAN HAMA TANAMAN JATI RAKYAT DAN UPAYA PENGENDALIANNYA DI RUMPIN, BOGOR
}

\author{
Infestation Potential of Pest on Community's Teak Plantation and Expedient \\ Control in Rumpin, Bogor \\ Nanang Herdiana \\ Balai Penelitian Kehutanan (BPK) Palembang \\ Jl. Kol. H. Burlian Km. 6,5 Puntikayu PO. BOX. 179, Palembang \\ Telp./Fax. (0711) 414864 \\ e-mail : nanang_herdiana@yahoo.co.id
}

Naskah masuk : 21 September 2009; Naskah diterima : 17 September 2010

\begin{abstract}
Teak (Tectona grandis Linn.) is one of potential forest plants that is developed especially for sawn wood. In growing period, it was often attacked by several pests that caused seriously damages. This research was conducted to identify kind of main pest organisms and determine the damage intensity. The inventory and identification of pests were done at a private teak plantation Rumpin, Bogor West Java and Forest Protection Laboratory, Bogor Agricultural University. The results showed that the main pests on teak plantations at the research location were Leucopholis rorida F. and Zeuzera coffeae Nietn. The highest damage caused by L. rorida was recorded on plot I (teak was 2.5 years old) with attack and damage intensity of $77.63 \%$ and $48.89 \%$ respectively. Beside this, the highest damage caused by Z. coffeae occured on plot IV (teak was 11 months old) with attack and damage intensity were $5.2 \%$ and $3.71 \%$ respectively.
\end{abstract}

Keywords: Teak (Tectona grandis Linn.), pests, Leucopholis rorida F., Zeuzera coffeae Nietn.

\begin{abstract}
ABSTRAK
Jati (Tectona grandis Linn.) merupakan salah satu jenis tanaman hutan potensial yang banyak dikembangkan, terutama untuk kayu pertukangan. Dalam pertumbuhannya, tanaman jati sering diserang oleh berbagai jenis hama yang dapat menimbulkan kerugian yang cukup serius. Penelitian ini bertujuan untuk mengetahui jenis hama utama dan dampak kerusakan yang ditimbulkan. Kegiatan inventarisasi dan identifikasi hama dilakukan pada tanaman jati rakyat di Rumpin, Bogor Jawa Barat dan Laboratorium Perlindungan Hutan Institut Pertanian Bogor. Hasil penelitian menunjukkan jenis hama utama yang menyerang tanaman jati pada lokasi penelitian adalah Leucopholis rorida $\mathrm{F}$. dan Zeuzera coffeae Nietn. Kerusakan akibat serangan uret paling parah terjadi pada petak I (jati umur 2,5 tahun) dengan intensitas serangan dan kerusakan masing-masing sebesar 77,63\% dan 48,89\%. Sedangkan serangan hama Z. coffeae paling parah terjadi pada petak IV (jati umur 11 bulan) dengan intensitas serangan dan kerusakan masing-masing sebesar $5,2 \%$ dan $3,71 \%$.
\end{abstract}

Kata kunci : Jati (Tectona grandis Linn.), hama, Leucopholis rorida F., Zeuzera coffeae Nietn.

\section{PENDAHULUAN}

Keberhasilan pembangunan hutan tanaman tidak hanya ditentukan oleh penguasaan dan penerapan teknik silvikultur yang sesuai dan taat azas, tetapi juga dipengaruhi oleh aspek lainnya seperti perlindungan terhadap hama maupun penyakit. Serangan hama dan penyakit dapat menurunkan potensi tegakan, baik kualitas maupun kuantitasnya. Dalam sistem silvikultur intensif, perlindungan hama dan penyakit menjadi salah satu komponen penting, di samping penggunaan materi dengan kualitas genetik unggul dan manipulasi lingkungan.

Jati (Tectona grandis Linn.) merupakan salah satu jenis tanaman hutan andalan yang banyak dikembangkan karena mempunyai sifatsifat yang baik, terutama untuk kayu 
pertukangan. Dalam pertumbuhannya, tanaman jati sering diserang oleh berbagai jenis hama yang dapat menimbulkan kerugian yang cukup serius. Beberapa jenis hama yang umum menyerang tanaman jati di Indonesia antara lain: Xyleborus destruens Bldf. dan Neotermes tectonae Damm. (menyerang batang), Captotermes curvignatus Hciver. dan Leucopholis rorida F. (menyerang akar), Duomitus ceramicus Wlk. dan Monochamus rusticator Fab. (menyerang kambium sampai kayu pohon/xylem), Hiblaea puera Cr. dan Pyrausta machaeralis Wills. (menyerang daun) dan Phassus damor Morr. (menyerang leher akar) (Suratmo, 1979 dalam Rahardjo, 1989).

Berdasarkan pengamatan awal, tegakan jati rakyat di Rumpin mengalami serangan hama yang mengakibatkan kerusakan pada sebagian besar populasi berupa mengeringnya pucuk, kemudian ranting sampai batang secara keseluruhan yang pada akhirnya kematian pada pohon. Sehubungan dengan permasalahan tersebut, maka dilakuan pengamatan untuk mengetahui jenis hama utama yang menyerang tegakan jati tersebut, dampak kerusakan yang ditimbulkan dan potensi upaya pengendaliannya.

\section{METODOLOGI}

\section{A. Lokasi dan Waktu}

Kegiatan penelitian survei lapangan dilakukan pada tanaman jati rakyat di Rumpin, Bogor, Jawa Barat. Bahan tanaman awal yang digunakan untuk pembangunan tegakan ini berasal dari kultur jaringan. Identifikasi terhadap hama yang diperoleh dari lapangan dilakukan di Laboratorium Perlindungan Hutan Fakultas Kehutanan Institut Pertanian Bogor. Kegiatan penelitian tersebut berlangsung mulai bulan September - Oktober 2000.

\section{B. Bahan dan Alat}

Bahan yang digunakan sebagai obyek pengamatan adalah tegakan jati rakyat berumur 2,5 tahun (petak I), 16 bulan (petak II dan III), 11 bulan (petak IV) dan 4 bulan (petak V) yang berlokasi di Rumpin, Bogor Jawa Barat, etanol, tali rafia dan kapas. Sedangkan peralatan yang digunakan antara lain : pengukur tinggi (meteran), golok, pilok, tabung bekas film, alat tulis dan kamera.

\section{Metoda Penelitian}

Kegiatan survey lapangan dilakukan meliputi pengamatan terhadap karakteristik serangan hama, inventarisasi inang terserang, identifikasi gejala dan tanda serangan serta pengamatan kondisi lingkungan sekitar. Kegiatan pengamatan dilakukan terhadap semua individu pohon yang ada di lokasi (sensus). Kegiatan identifikasi jenis hama yang diperoleh dilakukan di laboratorium.

Pengamatan terhadap individu pohon yang terserang dilakuan untuk mengetahui intensitas kerusakan berdasarkan jenis hama yang menyerang, meliputi:

a. Hama perusak akar. Parameter yang diukur meliputi: Tinggi pohon total dan tinggi batang yang masih hidup (dilihat berdasarkan ada tidaknya tunas yang tumbuh pada batang).

b. Hama penggerek batang. Parameter yang diukur meliputi: Ketinggian lubang gerek, jumlah lubang gerek dan kondisi tajuk.

\section{Analisis Data}

Parameter pengukuran yang analisis adalah intensitas serangan dan intensitas kerusakan.

\section{Intensitas serangan}

Diperoleh berdasarkan perhitungan jumlah pohon yang terserang hama dan jumlah semua pohon dalam petak pengamatan (sehat dan yang terserang), rumus yang digunakan adalah:

$$
\text { IS } \quad \frac{N h}{N t} \quad x \quad 100 \%
$$

di mana: IS = Intensitas serangan $(\%)$

$$
\begin{aligned}
\mathrm{Nh}= & \text { Jumlah pohon yang terserang } \\
& \text { dalam petak pengamatan } \\
\mathrm{Nt}= & \text { Jumlah total pohon yang ada } \\
& \text { dalam petak pengamatan }
\end{aligned}
$$

\section{Intensitas kerusakan}

Diperoleh berdasarkan klasifikasi dari parameter yang diukur pada individu pohon yang terserang dan akibatnya pada pohon itu sendiri. Intensitas kerusakan untuk serangan hama perusak akar menggunakan perbandingan antara tinggi batang yang mati dengan tinggi total pohon. Sedangkan klasifikasi yang digunakan untuk hama perusak batang dapat dilihat pada Tabel 1. 
Tabel(Table) 1. Klasifikasi dan tanda-tanda kerusakan jati akibat serangan hama penggerek batang (The Classification and symptoms of teak damage caused by stem borer)

\begin{tabular}{|c|c|c|}
\hline & $\begin{array}{l}\text { Parameter kerusakan } \\
\text { (Damage parameters) }\end{array}$ & $\begin{array}{l}\text { Nilai kerusakan } \\
\text { (Damage values) }\end{array}$ \\
\hline \multirow[t]{10}{*}{1.} & Tinggi lubang gerek (Height of borrer holes) & \\
\hline & a. Petak IV (jati umur 11 bulan) (Plot IV (teak was 11 months old)) & \\
\hline & $0-2 \mathrm{~m}$ & 3 \\
\hline & $2,1-4 \mathrm{~m}$ & 2 \\
\hline & $4,1-6 \mathrm{~m}$ & 1 \\
\hline & b. Petak V (jati umur 4 bulan) (Plot IV (teak was 4 months old)) & \\
\hline & $0-0,5 \mathrm{~m}$ & 4 \\
\hline & $0,6-1 \mathrm{~m}$ & 3 \\
\hline & $1,1-1,5 \mathrm{~m}$ & 2 \\
\hline & $1,6-2 \mathrm{~m}$ & 1 \\
\hline \multirow[t]{4}{*}{2.} & Kondisi tajuk (Canopy conditions) & \\
\hline & Mati/patah (Die/broken) & 2 \\
\hline & Layu (Wilt) & 1 \\
\hline & Sehat (Health) & 0 \\
\hline \multirow[t]{4}{*}{3.} & Jumlah lubang gerek (Number of borer holes) & \\
\hline & $>1$ & 2 \\
\hline & 1 & 1 \\
\hline & 0 & 0 \\
\hline
\end{tabular}

Intensitas kerusakan dihitung berdasarkan rumus yang dikemukakan oleh Wastie yang telah dimodifikasi (Prawirisumardjo, 1979 dalam Winaryati, 1984):

$$
I K \quad \frac{J_{s p}}{P \times N} \quad x \quad 100 \%
$$

di mana: $\mathrm{IK}=$ Intensitas kerusakan $(\%)$

$\mathrm{Jsp}=$ Jumlah nilai kerusakan dari $\mathrm{n}$ pohon yang terserang pada petak pengamatan
$\mathrm{P}=$ Nilai tertinggi dari jumlah nilai kerusakan dalam satu pohoN

$\mathrm{N}$ = Jumlah pohon yang ada dalam petak pengamatan

Penilaian intensitas kerusakan akibat serangan hama perusak batang dibagi kedalam beberapa katagori berdasarkan Bowner et al. (1995) dalam Winarto (1997) seperti yang disajikan pada Tabel 2 .

Tabel (Table) 2. Klasifikasi tingkat kerusakan jati akibat serangan hama penggerek batang (Clasification of teak damage caused by stem borer)

\begin{tabular}{|c|c|c|}
\hline No. & $\begin{array}{c}\text { Intensitas Kerusakan } \\
\text { (DamageIntensity) }(\%)\end{array}$ & Kategori (Category) \\
\hline 1. & 0 & Sehat \\
2. & $1-21$ & Ringan \\
3. & $21-40$ & Sedang \\
4. & $41-60$ & Agak berat \\
5. & $61-80$ & Berat \\
6. & $>80$ & Sangat berat \\
\hline
\end{tabular}




\section{HASIL DAN PEMBAHASAN}

\section{A. Identifikasi Jenis Hama, Serangan dan Dampak Kerusakan}

Berdasarkan pengamatan langsung di lapangan dan identifikasi di laboratorium diketahui dua jenis serangga hama yang berbeda dan menyerang pada petak tanaman jati (Tectona grandis Linn.) yang berbeda. Pada tanaman jati berumur 2,5 tahun (petak I) dan 16 bulan (petak II dan III) hama yang menyerang adalah serangga perusak akar, yaitu uret Leucopholis rorida F. (ordo Coleoptera, famili Melolonthidae). Sedangkan pada tanaman jati yang berumur 11 bulan (petak IV) dan 4 bulan (petak V) hama yang menyerang adalah serangga perusak pucuk, cabang dan batang yaitu Zeuzera coffeae Nietn. (ordo Lepidoptera, famili Cossidae).

\section{Leucopholis rorida $\mathrm{F}$.}

Uret, disebut juga embug atau gayas (Jawa Tengah dan Jawa Timur) dan kuuk (Jawa Barat) adalah larva dari kumbang yang tergolong ordo Coleoptra, subordo Lamellicornia. Uret yang ditemukan adalah Leucopholis rorida $\mathrm{F}$. termasuk famili Melolonthidae (Coulson, 1984). Uret dari famili ini termasuk salah satu yang paling banyak menyerang tanaman hutan (Intari dan Natawiria, 1973).

Jenis tanaman yang diserang oleh uret tidak hanya jati, tetapi dapat menyerang jenis tanaman hutan lainnya seperti rasamala. Seperti yang dilaporkan oleh Harsono (1981) bahwa pada tahun 1980 uret $L$. rorida menyerang tanaman rasamala berumur 2 tahun di daerah Cikaung, Sukabumi.

Uret kumbang ini mempunyai panjang mencapai $5 \mathrm{~cm}$, berwarna putih kekuningan, borstel (bulu-bulu) pada bagian ventral ujung abdomen uret tersusun dalam dua baris sejajar, banyaknya borstel tiap baris $15-27$ buah. Telurnya mula-mula berwarna putih berukuran 3 $\mathrm{mm}$, telur yang hampir menetas berubah menjadi $5 \mathrm{~mm}$ dan kulit telurnya menjadi keras.

Kumbang L. rorida berwarna coklat pada bagian atasnya dan pada bagian bawahnya berwarna coklat kemerahan. Permukaan tubuhnya ditutupi sisik renik berwarna putih kekuningan dan pada bagian belakang kepala, pangkal antena dan pro-, meso- dan metasternum tumbuh bulu-bulu halus berwarna kuning kecoklatan (Husaeni, 2000).

Telur-telurnya diletakkan secara tersebar di dalam tanah dengan kedalaman yang berbeda tergantung sifat fisik tanahnya, biasanya pada kedalaman $17-35 \mathrm{~cm}$, bahkan sampai kedalaman $40-50 \mathrm{~cm}$. Uret yang telah dewasa terdapat pada lapisan tanah yang lebih dalam. Kumbang yang baru keluar dari pupa tidak langsung keluar dari tanah, tetapi akan tinggal beberapa waktu lamanya di dalam tanah (Harsono, 1981). Di lapangan ditemukan kumbang yang masih lunak dan masih di dalam tanah. Kumbang akan keluar meninggalkan tanah pada awal musim hujan, terutama segera setelah hujan pertama turun. Selanjutnya akan mencari makan dan melakukan perkawinan dan kemudian akan kembali ke dalam tanah untuk bertelur.

Berdasarkan pengamatan di lapangan, gejala yang terlihat pada pohon yang terserang uret mula-mula daunnya layu kemudian menguning dan mengering, diikuti dengan mengeringnya ranting-ranting dan batang, pada pohon yang masih mampu bertahan hidup terlihat adanya tunas-tunas yang tumbuh pada batang tidak jauh dari permukaan tanah tetapi jika serangannya terus menerus dan cukup parah dapat mengakibatkan kematian pohon. Kondisi tegakan jati yang terserang uret $L$. rorida dapat dilihat pada Gambar 1.

Leucopholis termasuk golongan uret yang bahan makananya hanya berupa akar tanaman yang masih hidup (Husaeni, 2000). Pada saat pemeriksaan akar pohon yang diserang, terlihat bekas gigitan uret pada akar-akar cabang yang masih muda termasuk akar serabutnya dan ada beberapa bagian akar yang sudah mulai membusuk. Putusnya akar serabut akan menghambat penyerapan unsur hara dan air. Kondisi tersebut mengakibatkan bagian atas pohon mengering karena air yang mampu diserap oleh akar akan terbatas, sehingga tidak mampu untuk ditransportasikan ke bagian pucuk tanaman. Kondisi akar yang terserang uret $L$. rorida dapat dilihat pada Gambar 1.

Berdasarkan data intensitas serangan dan intensitas kerusakan (Tabel 3), terlihat bahwa intensitas serangan dan intensitas kerusakan tanaman jati akibat serangan hama uret cukup bervariasi dan termasuk kategori sedang - agak berat. Intensitas kerusakan serangan uret yang paling parah terjadi pada petak I (jati umur 2,5 tahun) sebesar $48,89 \%$ dan termasuk kategori agak berat. Perbedaan intensitas serangan pada ke tiga petak tersebut diduga berhubungan dengan sifat fisik tanah, pada petak I tanahnya paling gembur dibanding dua petak lainnya sedangkan uret memilih tanah yang gembur 
untuk bertelur, sehingga pada petak III yang mempunyai kondisi fisik tanah yang padat, tidak mendukung bagi perkembangan uret (Husaeni, 2000). Di samping perbedaan kondisi fisik tanah dari ke tiga petak tersebut, petak I berdekatan dengan kebun rambutan yang merupakan habitat kumbang $L$. rorida, karena kumbang ini memakan daun rambutan dan ketika akan bertelur, kumbang tersebut akan langsung masuk ke tanah di lokasi terdekat (petak I).

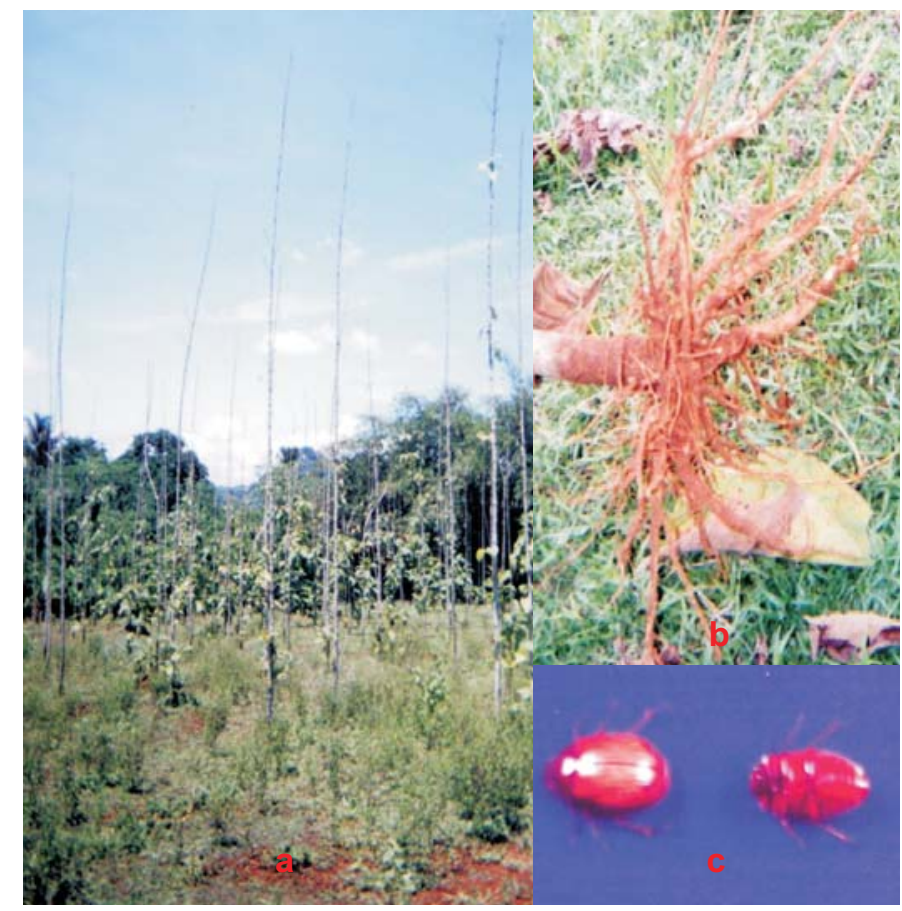

Gambar (Figure) 1. Hama uret Leucopholis rorida F. pada tanaman jati: (a). Gejala serangan, (b). Kondisi akar tanaman jati yang terserang $L$. rorida, (c). Kumbang $L$. rorida (L. rorida on teak trees : (a). Attack symptoms, (b). Root condition of teak attacked by L. rorida, (c) L. rorida beetles)

Tabel (Table) 3. Rekapitulasi intensitas serangan dan intensitas kerusakan akibat serangan L. rorida pada tanaman jati (The recapitulation of attack and damage intensity caused by L. rorida on teaktrees)

\begin{tabular}{|c|c|c|c|c|c|}
\hline \multirow{2}{*}{$\begin{array}{l}\text { Petak } \\
\text { (Plots) }\end{array}$} & \multirow{2}{*}{$\begin{array}{c}\text { Umur Tanaman } \\
\text { (Age of Plant) }\end{array}$} & \multicolumn{2}{|c|}{$\begin{array}{l}\text { Jumlah Pohon } \\
\text { (Number of Tree) }\end{array}$} & \multirow{2}{*}{$\begin{array}{c}\text { Intensitas } \\
\text { serangan } \\
\text { (Attack } \\
\text { intensity) (\%) }\end{array}$} & \multirow{2}{*}{$\begin{array}{c}\text { Intensitas } \\
\text { kerusakan } \\
\text { (Damage } \\
\text { intensity) (\%) }\end{array}$} \\
\hline & & $\begin{array}{l}\text { Sehat } \\
\text { (Healthy) }\end{array}$ & $\begin{array}{l}\text { Terserang } \\
\text { (Attacked) }\end{array}$ & & \\
\hline I & 2,5 tahun & 183 & 635 & 77,63 & 48,89 \\
\hline II & 16 bulan & 248 & 260 & 51,18 & 29,95 \\
\hline III & 16 bulan & 224 & 181 & 42,59 & 21,20 \\
\hline
\end{tabular}

\section{Zeuzera coffeae Nietn.}

Dalam dunia kehutanan di Indonesia Zeuzera coffeae Nietn. disebut penggerek cabang merah, karena tubuh larvanya berwarna merah bata dan menyerang cabang-cabang jati muda. Sebetulnya hama ini tidak hanya menyerang cabang, tetapi juga menyerang batang pohon dan berdasarkan pengamatan di lapangan hama ini menyerang batang bagian atas (pucuk) dan juga ditemukan pada bagian cabang.

Telur yang baru diletakkan berwarna merah muda, setelah 9 hari berubah menjadi 
merah tua dan berbintik hitam dengan ukuran $1 \mathrm{x}$ 0,5 mm (Husaeni, 2000). Larva dewasa mempunyai panjang tubuh $4 \mathrm{~cm}$, kepalanya berwarna coklat, perisai pronotumnya berwarna coklat dan mengeras, lebih melebar ke arah samping dari pada ke arah panjang tubuhnya dan pada tepi depannya melekuk, pada bagian belakangnya tumbuh deretan duri kecil yang mengarah ke belakang tubuh. Tujuh segmen pertama abdomen berwarna merah muda sampai coklat ungu di bagian atas dan bagian bawahnya berwarna kekuningan. Sedangkan segmen ke 8, 9 dan ke 10 berwarna kecoklatan dan pada segmen terakhir terdapat pelat yang mengkilat.
Pupanya berwarna coklat kastanye dengan panjang tubuh $2,5 \mathrm{~cm}$, di atas matanya terdapat tonjolan-tonjolan tumpul dan pada segmensegmen abdomen dorsal terdapat deretan gerigi yang melengkung ke belakang. Imagonya berupa ngengat berwarna putih, pada toraknya terdapat pasangan-pasangan bintik hitam dan pada sayap depan terdapat sejumlah bintik dan garis hitam dan pada ujung sayap belakang terdapat beberapa bintik hitam dan rentang sayapnya sekitar 35 - 45 $\mathrm{mm}$. Gambar Z. coffeae mulai dari stadia larva, pupa sampai dengan imagonya dapat dilihat pada Gambar 2.

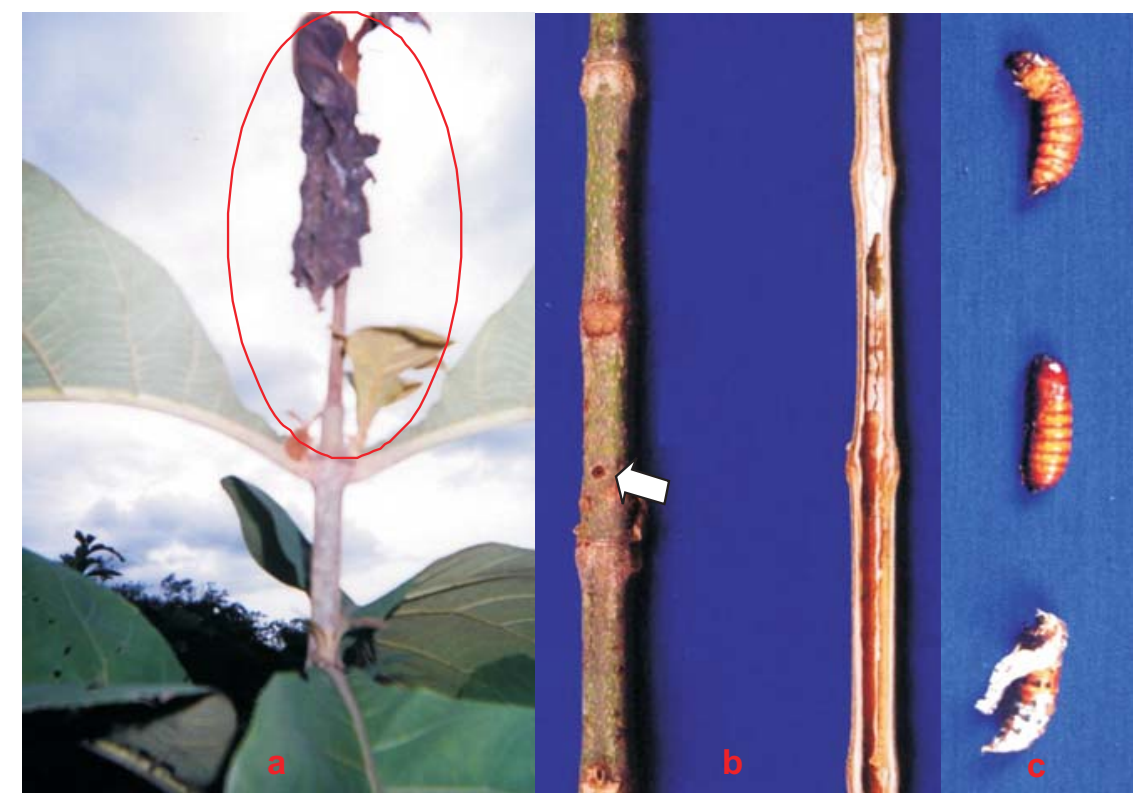

Gambar(Figure) 2. Hama penggerek batang (Z. coffeae) pada tanaman jati: (a). Gejala serangan, (b). Lubang (tanda panah) dan saluran gerek pada batang tanaman jati, (c). Metamorfosis hama Z. coffeae mulai dari larva, pupa dan imago (Stem borrer (Z. coffeae) on teak trees: (a). Attack symptoms, (b). Hole borrer (arrow sign) and canal borrer on teak stemps, (c). Metamorfose of Z. coffeae consist larva, pupa and imago)

Seekor ngengat betina mampu meletakkan 500 - 1000 butir telur dalam waktu 12 minggu. Siklus hidup $Z$. coffaea di Indonesia berkisar antara $4-5,5$ bulan, stadium telurnya berlangsung 12 hari, larva 53 - 56 hari, pupanya 21 - 28 hari dan ngengatnya 5 - 11 hari (Husaeni, 2000).

Gejala yang dapat dilihat pada pohon yang terserang $Z$. coffeae adalah kerusakan pada bagian pucuk tanaman akibat saluran gerek yang dibuatnya. Saluran gerek yang dibuat oleh larva muda terdiri dari dua bagian, bagian pertama sepanjang $1-2 \mathrm{~cm}$ ke arah pangkal dan bagian ke dua ke arah pucuk. Larva-larva yang lebih tua akan memperbesar saluran gerek ini dengan bentuk gerekan yang tidak teratur. Liang gerek ini akan menembus kambium dan daerah kulit, sehingga yang tertinggal hanya lapisan yang tipis dan jika ada angin akan mudah patah. Kadangkadang larva ini membuat saluran gerek yang melingkari batang atau cabang dan meneres batang sehingga bagian batang kayu di atasnya menjadi mati. Lubang dan saluran gerek yang dibuat oleh larva $Z$. coffeae dapat dilihat pada Gambar 2. 
Tabel(Table) 4. Rekapitulasi intensitas serangan dan intensitas kerusakan akibat serangan Z. coffaea pada tanaman jati (The recapitulation of attack and damage intensity caused by Z. coffeae attack on teak trees)

\begin{tabular}{|c|c|c|c|c|c|}
\hline \multirow{2}{*}{$\begin{array}{l}\text { Petak } \\
\text { (Plots) }\end{array}$} & \multirow{2}{*}{$\begin{array}{l}\text { Umur tanaman } \\
\text { (Age of plant) }\end{array}$} & \multicolumn{2}{|c|}{$\begin{array}{l}\text { Jumlah pohon } \\
\text { (Number of tree) }\end{array}$} & \multirow{2}{*}{$\begin{array}{c}\text { Intensitas } \\
\text { serangan } \\
\text { (Attack } \\
\text { intensity) (\%) }\end{array}$} & \multirow{2}{*}{$\begin{array}{c}\text { Intensitas } \\
\text { kerusakan } \\
\text { (Damage } \\
\text { intensity) }(\%)\end{array}$} \\
\hline & & $\begin{array}{c}\text { Sehat } \\
\text { (Healthy) }\end{array}$ & $\begin{array}{l}\text { Terserang } \\
\text { (Attacked) }\end{array}$ & & \\
\hline IV & 11 bulan & 2.013 & 111 & 5,22 & 3,71 \\
\hline V & 4 bulan & 1.143 & 11 & 0,95 & 0,68 \\
\hline
\end{tabular}

Berdasarkan data intensitas serangan dan intensitas kerusakan (Tabel 4) terlihat bahwa serangan $Z$. coffeae yang paling parah terjadi pada petak IV (jati umur 11 bulan), tetapi masih termasuk dalam kategori ringan. Walaupun serangan $Z$. coffeae pada petak $\mathrm{V}$ tidak begitu tinggi, tetapi karena tanamannya masih muda maka resiko terjadinya kerusakan yang lebih parah dan kemungkinan terjadinya kematian tanaman akan lebih besar dibanding petak IV.

Kerusakan akibat serangan Z. coffea, berupa patahnya pucuk atau bagian atas pohon baik masih segar atau sudah layu maupun sudah mati, namun ada juga yang masih tetap tegak walaupun sudah mati (die back). Dampak dari kerusakan semacam itu terutama pada tanaman yang masih muda akan mengurangi tinggi bebas cabang yang dapat terbentuk. Serangan hama ini juga menyebabkan tumbuhnya pertunasan di bawah bagian batang yang terserang, batang menjadi bengkok dan berlubang, sehingga dapat menurunkan kuantitas dan kualitas kayu yang dapat dihasilkan (panjang sortimen yang dapat dibuat).

Pada tegakan jati yang berasal dari vegetatif makro (stek) atau organ generatif (benih), terjadinya serangan hama dan penyakit secara besar-besaran seperti pada lokasi penelitian ini belum pernah dilaporkan. Resistensi tanaman terutama yang berasal dari kultur jaringan dapat dipengaruhi oleh proses pembuatannya. Pada proses pembuatan tanaman melalui kultur jaringan kemungkinan dapat terjadi soma clonal variation, jika penanganannya kurang hati-hati. Keadaan ini akan menyebabkan ketidakstabilan genetik tanaman yang akan berpengaruh terutama pada menurunnya intensitas resistensi tanaman terhadap serangan hama dan penyakit.

\section{B. Upaya Pengendalian}

\section{Pengendalian Leucopholis rorida $\mathrm{F}$.}

Jika dibiarkan serangan uret ini dapat mematikan semua tanaman yang ada, tindakan pengendalian harus sesegera mungkin dilakukan untuk mengurangi terjadinya serangan yang lebih parah dan menghindari penularan ke tegakan jati lainnya yang belum terserang. Tindakan pengendalian yang bertujuan untuk mencegah dan mengurangi serangan uret dapat dilakukan secara mekanis maupun kimiawi, secara teknis tindakan tersebut dapat dilakukan dengan cara sebagai berikut :

a. Pembersihan gulma dan pendangiran tanah di sekitar tanaman, adanya gulma yang tumbuh memberikan pengaruh yang mendukung terhadap perkembangan uret yang ada di dalam tanah dan biasanya tanah yang dipilih kumbang untuk bertelur adalah tanah yang bervegetasi dan lembab, dengan pembersihan gulma dan pendangiran maka sinar matahari dapat langsung sampai di tanah sehingga suhu tanah akan meningkat di samping akan mempermudah pada saat dilakukan pemupukan tanaman.

b. Pengurangan populasi kumbang, dilakukan dengan penangkapan kumbang yang sudah ke luar dari tanah dan yang hidup pada pohon inang. Berdasarkan pengamatan di lapangan, L. rorida hanya pada stadia larva hidup di dalam tanah dan setelah menjadi imago (kumbang) akan ke luar untuk mencari makan dan melakukan perkawinan, tanaman inang kumbang ini adalah pohon rambutan dan pisang. Sehingga diupayakan agar tidak menanam pohon rambutan atau pisang yang berdekatan dengan tanaman jati.

c. Musim terbang kumbang akan segera diikuti oleh musim bertelur. Oleh karena itu dalam bulan-bulan pertama musim kumbang terbang 
(sebelum musim hujan) harus segera dilakukan pemberian insektisida pada tanah atau lubang tanam, untuk mencegah serangan uret yang baru menetas. Insektisida yang dapat digunakan adalah yang berbahan aktif karbofuran, misalnya furadan (Tini dan Khairul, 2002).

d. Uret tergolong serangga polifag yang tidak hanya memakan tanaman kehutanan namun juga tanaman palawija, salah satu tanaman palawija yang paling disukai adalah singkong, sehingga sebaiknya dihindari penanaman singkong pada lahan yang berdekatan dengan lokasi penanaman jati apalagi ditumpangsarikan.

\section{Pengendalian Zeuzera coffeae Nietn}

Serangan $Z$. coffeae pada tegakan jati yang ada di lokasi penelitian (petak IV dan V) termasuk belum parah, tetapi harus secepatnya dilakukan tindakan pengendalian sebelum serangannya meningkat dan menimbulkan kerugian yang cukup serius.

Sampai saat ini pengendalian yang efektif terhadap serangan $Z$. coffeae belum bayak diteliti dan masih terbatas pada pengendalian secara mekanis, yaitu dengan cara memangkas/ memotong batang (pucuk) yang terserang dan membunuh larvanya. Yang perlu diperhatikan pada saat melakukan pemangkasan adalah menghindari kemungkinan infeksi dari mikroorganisme lain seperti jamur atau bakteri yang dapat masuk melalui luka pada batang yang dipangkas. Untuk menghindari hal tersebut dapat dilakukan dengan pemberian ter pada bekas pemangkasan. Sedangkan pengendalian secara kimiawi yang dapat dilakukan adalah dengan menggunakan insektisida berbahan aktif dimetoat, diaplikasikan dengan cara disumbatkan dalam lubang gerek menggunakan kapas (Tini dan Khairul, 2002).

Walaupun pengendalian hayati tidak efektif jika diterapkan di lapangan, tetapi berdasarkan penelitian yang pernah dilakukan ditemukan serangga parasitoid dari famili Braconidae yang menyerang larva dan pupa $Z$. coffeae. Sedangkan musuh alami lainnya adalah burung pelatuk.

Metoda pengendalian lain yang dapat dikembangkan adalah penggunaan perangkap cahaya. Imago $Z$. coffeae adalah ngengat yang aktif pada malam hari dan pada umumnya ngengat akan tertarik pada cahaya lampu. Sehingga jika ngengat tersebut dapat ditangkap, maka akan dapat mengurangi populasi serangan $Z$. coffeae dan resiko terjadinya serangan yang parah.

\section{KESIMPULAN}

Jenis hama yang menyerang tanaman jati (Tectona grandis Linn.) pada lokasi penelitian adalah uret Leucopholis rorida F. (serangga perusak akar) dan Zeuzera coffeae Nietn. (serangga perusak pucuk dan cabang). Kerusakan akibat serangan uret paling parah terjadi pada petak I (jati umur 2,5 tahun) dengan intensitas serangan dan intensitas kerusakan masing-masing sebesar 77,63\% dan $48,89 \%$, sehingga sebaiknya tanaman jati tersebut diganti.

Tindakan pengendalian yang dapat dilakukan adalah pembersihan dan pendangiran sekitar tanaman, penggunaan insektisida berbahan aktif karbofuran dan penangkapan terhadap uret dan kumbangnya.

Serangan hama $Z$. coffeae paling parah terjadi pada petak IV (jati umur 11 bulan) dengan intensitas serangan dan intensitas kerusakan masing-masing sebesar $5,2 \%$ dan $3,71 \%$. Tindakan pengendalian mekanis yang dapat dilakukan adalah pemangkasan pucuk yang terserang dan membunuh larvanya.

\section{DAFTAR PUSTAKA}

Coulson, R. N. and J. A. Witter. 1984. Forest Entomology; Ecology and Management. Willey Intersci. Publ. New York.

Harsono, D. P. B. 1981. Serangan Hama Uret pada Tanaman Muda Rasamala di KPH Ciguha, BKPH Cikaung, KPH Sukabumi. Skripsi Jurusan Manajemen Hutan, Fakultas Kehutanan, Institut Pertanian Bogor. Bogor.

Husaeni, E. A. 2000. Diktat Hama Hutan Tanaman di Indonesia. Fakultas Kehutanan, Institut Pertanian Bogor. Bogor.

Intari, S. E. dan D. Natawiria. 1973. Hama Uret pada Persemaian dan Tegakan Muda. Laporan No. 167. LPH. Bogor.

Rahardjo, E. 1989. Pengaruh Curah Hujan terhadap Serangan Xyleborus destruens Bldf. pada Tegakan Jati di RPH Gadung 
(BKPH Banjar Utara, KPH Ciamis) dan RPH Kedungpani (BKPH Boja, KPH Kendal). Skripsi Jurusan Manajemen Hutan, Fakultas Kehutanan, Institut Pertanian Bogor. Bogor.

Tini, Nia dan K. Amri. 2002. Mengebunkan Jati Unggul : Pilihan Investasi Prospektif. Agro Media Pustaka. Jakarta.

Winarto, B. 1997. Studi Keragaman Gejala, Morfologi, Patogenitas dan Intensitas Penyakit Diplocarpon rosae pada Mawar.
Prosiding Kongres Nasional dan Seminar Ilmiah Perhimpunan Fitopatologi Indonesia. Palembang, 27 - 29 Oktober 1997. Palembang.

Winaryati, A. 1984. Derajat Kerusakan dan Kerugian Akibat Serangan Ingeringer (Neotermes tectonae Damm.) di BKPH Boto KPH Randublatung. Skripsi Jurusan Manajemen, Hutan Fakultas Kehutanan, Institut Pertanian Bogor. Bogor. 